Biomedical

Research \& Therapy

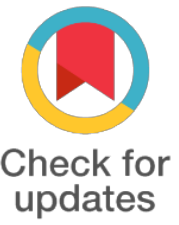

*For correspondence:

ggajski@imi.hr

Competing interests: The authors declare that no competing interests exist.

Received: 06 March 2017 Accepted: 28 July 2017 Published: 27 June 2017

Copyright The Author(s) 2017. This article is published with open access by BioMedPress (BMP).

This article is distributed under the terms of the Creative Commons Attribution License (CC-BY 4.0) which permits any use, distribution, and reproduction in any medium, provided the original author(s) and the source are credited.

\section{Anticancer effects of natural products from animal and plant origin}

\author{
Goran Gajski ${ }^{1}$, Josip Madunić ${ }^{2}$, Ivana Vrhovac Madunić ${ }^{1}$, Tamara Čimbora- \\ Zovko ${ }^{3}$, Sanjica Rak ${ }^{3}$, Davorka Breljak ${ }^{1}$, Maja Osmak ${ }^{3}$ and Vera Garaj- \\ Vrhovac $^{1}$ \\ ${ }^{1}$ Institute for Medical Research and Occupational Health, 10000 Zagreb, Croatia \\ ${ }^{2}$ Faculty of Science, University of Zagreb, 10000 Zagreb, Croatia \\ 3Ruđer Bošković Institute, 10000 Zagreb, Croatia
}

\begin{abstract}
For last couple of decades, natural products have served us well in combating different types of cancer. The main sources of these useful compounds are from both animal and plant origin. Here we will present anticancer ability of bee venom (BV) and apigenin (API) towards different types of cancer cells in vitro. BV from honey bees is a complex mixture of a variety of different active peptides while API is a natural flavonoid found in several dietary plant foods. Anticancer effect of whole BV was tested in human cervical carcinoma HeLa cells and their drug-resistant HeLa CK subline while anticancer effect of API was tested in human breast cancer MCF-7 and MDA MB-231 cells. Cytotoxicity of both compounds towards cancer cells was evaluated by MTT assay whereas type of cell death was analysed by differential staining using acridine orange/ethidium bromide and was further verified by Western blot analysis. BV displayed dose-dependent cytotoxicity against both cell lines tested with drug-resistant HeLa CK cells being more sensitive to BV than their parental cell lines. Similarly, API inhibited the growth of both cell lines in a dose-dependent manner with MCF-7 cells being more sensitive. Treatment with BV induced a necrotic type of cell death, as shown by characteristic morphological features, fast staining with ethidium bromide and a lack of cleavage of apoptotic marker poly (ADP-ribose) polymerase (PARP) on Western blot. On the contrary, cell treated with API showed apoptosis as a dominant type of cell death in both cell lines which was further verified by Western blot analysis detecting cleaved PARP. In view of accumulating evidence on anti-proliferative and pro-cell death activity, both tested compounds could be used in the development of future anticancer drugs. Undoubtedly, therapeutic applications of BV and API are promising, however further in vitro and in vivo studies are warranted to resolve precise mechanisms responsible for their anticancer properties.
\end{abstract}

\section{Keywords}

bee venom, apigenin, human cervical carcinoma cells, human breast cancer cells, anticancer effects

Funding

References 